\title{
PENGARUH PENDAPATAN ASLI DAERAH TERHADAP BELANJA DAERAH PADA PEMERINTAH KOTA DI PULAU JAWA
}

\author{
${ }^{1}$ Ade Pipit Fatmawati, ${ }^{2}$ Nabilla Ria Sari \\ Program Studi D4 Akuntansi Keuangan \\ Politeknik Pos Indonesia \\ adepipitfatmawati@gmail.com, nabillaria25@gmail.com
}

\begin{abstract}
ABSTRAK
Kebijakan swatantra wilayah membawa perubahan yang sangat fundamental pada peningkatan PAD. Penelitian ini bertujuan untuk mengetahui pengaruh antara Pendapatan Asli Daerah terhadap Belanja Daerah pada Pemerintah Kota di Pulau Jawa yang terdaftar di djpkkemekeu. Metode yg dipakai pada penelitian ini adalah metode kuantitatif menggunakan jenis perumusan kasus asosiatif yg memiliki interaksi karena akibat (kausal) . Penelitian ini memakai data sekunder berupalaporan keuangan APBD yg terdaftar pada djpkkemkeu. Populasi yang digunakan dalam penelitian ini adalah pemerintah kota di pulau jawa yang berjumlah 34 pemkot, serta pengambilan sampel dilakukan menggunakan metode nonprobability sampling dengan teknik sampling purposive. Teknik analisis data yg dipakai pada penelitian ini merupakan korelasi product moment, regresi linier sederhana, koefisien determinasi, dan uji t. Hasil penelitian ini menampakan bahwa PAD secara parsial masih ada imbas yg signifikan terhadap pemerintah kota pada pulau jawa dan Belanja Daerah secara parsial masih ada imbas yg signifikan terhadap pemerintah kota pada pulau jawa. Sedangkan secara simultan terdapat pengaruh yang signifikan antara PAD terhadap Belanja Daerah .
\end{abstract}

Kata kunci: Pendapatan Asli Daerah dan Belanja Daerah

\section{ABSTRACT}

The regional autonomy policy brings fundamental changes to the increase in PAD. This study aims to determine the effect of Regional Original Income on Regional Expenditures at the City Government in Java Island which is registered in djpkkemekeu . The method used in this research is the quantitative method using the type of associative case formulation which has causal interactions. "This study uses secondary data in the form of $A P B D$ financial reports registered with djpkkemkeu. . The population used in this study is the city government in the island of Java, amounting to 34 municipalities, and the sampling is done using nonprobability sampling method with purposive sampling technique. The data analysis techniques used in this study are product moment correlation, simple linear regression, coefficient of determination, and t test. The results of this study show that partially PAD still has a significant impact on the city government on the island of Java and partially there is still a significant impact on the regional government on the island of Java. Meanwhile, simultaneously there is a significant influence between PAD on Regional Expenditures

Keyword: Local Own Revenue and Regional Expenditure 


\section{PENDAHULUAN}

Reformasi pemerintahaan yang disertai dengan keterbukaan sudah menjadi tuntutan di Indonesia. Hal ini menyebabkan semakin menguatnya tuntutan aspek transparasi dan akuntanbilitas . Kedua aspek tersebut menjadi penting dalam pengelolaan keuangan negara maupun daerah. Sesuai dengan amanat UUD RI tahun 1945, pemerintah daerah berwenang untuk mengatur dan mengurus sendiri urusan pemerintahan menurut asas otonomi dan tugas pembantuan. Diberlakukannya otonomi wilayah bisa menaruh kesempatan Pemda lebih supaya mengembangkan potensi wilayah, wewenang buat mengelola asal daya yg wilayah miliki secara efisien \& efektif , \& meningkatkan kinerja keuangan wilayah. Kebijakan otonomi daerah membawa perubahan yang sangat mendasar dalam peningkatan PAD . Dengan adanya otonomi daerah, berbagai daerah berlomba untuk melakukan inovasi demi terciptanya daerah yang mandiri, hal itu bisa dilihat dari pertumbuhan PAD yang semakin meningkat dan semakin besarnya kontribusi PAD tersebut terhadap belanja daerah .

Anggaran daerah juga digunakan sebagai alat untuk menentukan besar pendapatan dan pengeluaran. Penyusunan APBD tersebut disesuaikan dengan kebutuhan penyelenggaraan pemerintahaan dan kemampuan pendapatan daerah . Dapat digambarkan secara garis besar, struktur APBD yaitu pendapatan daerah, belanja daerah, dan pembiayaan daerah. Adapun APBD dapat memuat saran menurut fungsi belanja, standar pelayanan yang diharapkan dan perkiraan biaya suatu komponen kegiatan yang bersangkutan .

Adapun fenomena yang terjadi pada pemerintah kota di pulau jawa yaitu Berdasarkan berita yang dikemukakan oleh beritadaerah.co.id pada 26 Desember 2019 "Realisasi APBD Pulau Jawa 2019". Secara keseluruhan tahun 2019, pertumbuhan pada ekonomi Jawa asal berdasarkan sisi domestik, terutama konsumsi swasta, ditopang penigkatan alokasi sang aturan acara buat sosial Pemerintah . Terdapat enam provinsi didalamnya yaitu DKI Jakarta, JawaBarat, Jawa Tengah, Yogyakarta \& Jawa Timur. Total Belanja Daerah Jawa berjumlah Rp 63.660 milyar atau $56.28 \%$ dari APBD sebesar Rp 113.105 milyar . Berdasarkan fenomena tersebut dapat kita ketahui bahwa APBD Pemerintah Kota Yogyakarta mengalami penurunan terbesar diantara Pemerintah Kota di Pulau Jawa periode triwulan III 2019

Berikut data yang diperoleh dari laporan belanja daerah yang terdiri dari belanja daerah langsung dan tidak langsung Pemerintah Kota di Pulau Jawa dapat dilihat:

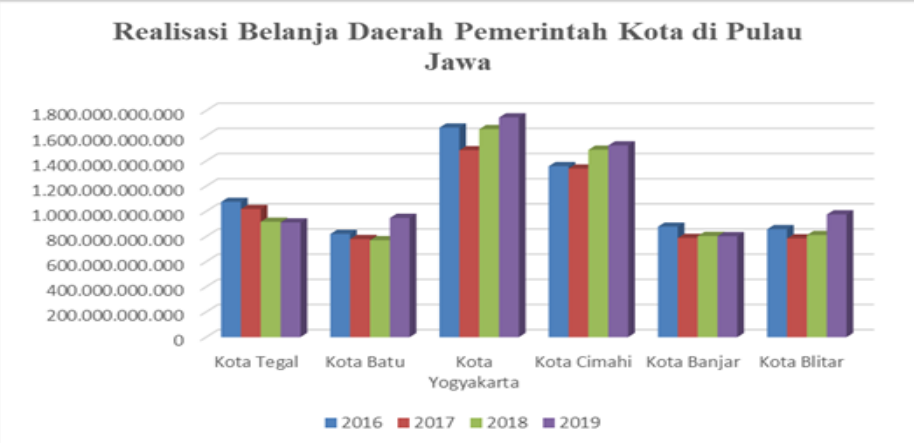

Gambar 1. Realisasi Belanja Daerah Pemerintah Kota di Pulau Jawa

Sumber : Diolah Penulis (2020)

Pada grafik 1 dapat terlihat bahwa Belanja Daerah pada setiap kota masih mengalami fluktuasi dari tahun ke tahun. Adapun faktor penurunan terhadap belanja daerah karena adanya perubahan dalam penerimaan, khususnya pendapatan . Adapun pertumbuhan belanja bisa diikuti menggunakan adanya pertumbuhan pendapatan yg 
seimbang, yg mana apabila nir maka pada jangka menengah akan mengganggu transedental juga kesehatan fiskal daerah . Dari perspektif agency theory, waktu waktu penyusunan APBD murni, eksekutif (dan dapat juga menggunakan sepengetahuan dan/atau persetujuan legislatif)sasaran PAD ditetapkan pada bawah potensi, selanjutnya dilakukan "adjustment" waktuwaktu dilakukan perubahan APBD .

Berdasarkan beberapa penelitian terdahulu yang diuraikan sebelumnya oleh (Dermawan, Wildan, 2017) berjudul "Pengaruh Pendapatam Asli Daerah (PAD) Terhadap Belanja Daerah". Hasil pengujian hipotesis memberitahukan bahwa PAD berpengaruh signifikan terhadap belanja daerah . Halini ditinjau menurut adanya impak Pendapatan Asli Daerah Terhadap Belanja Daerahsecara signifikan ini berarti bahwa semakin semakin tinggi Pendapatan Asli Daerahmaka akan semakin semakin tinggi juga Belanja Daerahnya .

Penelitian sebelumnya juga dilakukan oleh (Hidayat, Anwar, Doni, 2016) berjudul "Pengaruh Pendapatan Asli Daerah (Pad) Dan Dana Alokasi Umum (DAU) Terhadap Belanja Daerah Se Jawa Timur". Hasil penlitian mununjukkan nilai signifikansi pada uji-F yang lebih kecil dari alpa. Maka Secara simultan hal ini menunjukan bahwa variable Pendapatan Asli Daerh (PAD) dan Dana Alokasi Umum (DAU) berpengaruh terhadap belanja daerah

Penelitian oleh (Aminus, Rahmi, 2018) yang berjudul "Pengaruh Pendapatan Asli Daerah Dan Dana Perimbangan Terhadap Belanja Daerah Kabupaten Ogan Ilir". Hasil penelitianya menandakan bahwa pendapatan orisinil wilayah \& dana perimbangan memengaruhi belanja wilayah kabupaten Ogan Ilir."Variabel belanja wilayah ditentukan sang PAD \&dana perimbangan, sedangkan ditentukan sang faktor lain yg nir termasukpada penelitian ini .

Penelitian berikutnya dilakukan oleh (Wati, Masayu \& Fajar, Catur, 2017) berjudul "Pengaruh Pendapatan Asli Daerah dan Dana Perimbangan Terhadap Belanja Daerah Kota Bandung". Hasil penelitiannya menyatakan bahwa secara simultan maka bisa diketahui terdapatimbas yg signifikan antara pendapatan orisinil wilayah \& dana perimbanganterhadap belanja wilayah Kota Bandung .

Adanya fenomena diatas maka penulis tertarik untuk melakukan penelitian yang berjudul "Pengaruh Pendapatan Asli Daerah (PAD) terhadap Belanja Daerah pada Pemerintah Kota di Pulau Jawa". Dan yang menjadi identifikasi masalah dalam penelitian ini yaitu :

1. Bagaimana Pendapatan Asli Daerah (PAD) di Pemerintah Kota Pulau Jawa?

2. Bagaimana Belanja Daerah di Pemerintah Kota Pulau Jawa?

3. Bagaimana pengaruh Pendapatan Asli Daerah (PAD) terhadap Belanja Daerah pada Pemerintah Kota di Pulau Jawa?

\section{KAJIAN PUSTAKA}

\section{Pendapatan Asli Daerah (PAD)}

Menurut (Nurkholis \& Khusaini, 2019) "PAD adalah pendapatan yang diperoleh dari penerimaan pajak daerah, retribusi daerah, laba perusahaan daerah, dan lain-lain yang sah . Definisi lain, PAD adalah sebagai sumber pembiayaan pemerintah daerah, PAD dapat dihasilkan melalui beberapa sumber penerimaan terdiri dari hasil pajak daerah, hasil retribusi daerah, hasil perushaan milik dan hasil pengelolaan kekayaan daerah lainnya yang dipisahkan, dan lain-lain pendapatan asli daerah yang sah .

Berdasarkan (Undang-Undang No.33 Pasal 1 Angka 18, 2004) tentang perimbangan keuangan antara pemerintah pusat dan daerah, PAD didefinisikan sebagai pendapatan yang diperoleh daerah yang dipungut berdasarkan peraturan daerah sesuai dengan peraturan perundang-undangan . 
Menurut Pasal 6 UU No. 33 Tahun 2004 ayat 1 dan 2 dalam (Wulandari, Phaureula \& Iryanie, 2018) menyatakan bahwa PAD bersumber dari :

1. Pajak Daerah

2. Retribusi Daerah

3. Hasil perusahaan milik daerah dan hasil pengelolaan kekayaan milik daerah yang dipisahkan

\section{Belanja Daerah}

4. Lain-lain pendapatan asli daerah sah

Menurut (Wulandari, Phaureula \& Iryanie, 2018) "Belanja Daerah adalah semua kewajiban daerah yang diakui sebagai pengurang nilai kekayaan bersih dalam periode tahun anggaran yang bersangkutan".

Menurut Undang-Undang Republik Indonesia Nomor 33 Tahun 2004 dalam (Amin, 2019) tentang Perimbangan Keuangan Pusat dan Daerah, Belanja Daerah adalah semua kewajiban daerah yang diakui sebagai pengurangan nilai kekayaan bersih dalam periode tahun anggaran yang bersangkutan .

(Amin, 2019) sebagaimana diatur dalam Peraturan Pemerintahan Nomor 58 Tahun 2005 yang kemudian dijabarkan dalam Permendagri 13 Tahun 2006, belanja pemerintah daerah diklasifikasikan berdasarkan dua jenis belanja yaitu :

1. Belanja Tidak Langsung dan

2. Belanja Langsung

Menurut (Undang-Undang Nomor 32, 2004) menyebutkan bahwa Belanja daerah adalah semua kewajiban daerah yang diakui sebagai pengurang nilai kekayaan bersih dalam periode tahun anggaran yang bersangkutan. Belanja daerah dikelompokkan sebagai 2 jenis yaitu belanja nir pribadi \& belanja pribadi, belanja nir pribadi terdiri menurut belanja pegawai, belanja bunga, belanjasubsidi, belanja hibah, belanja donasi sosial belanja bagi hasi kepadaProvinsi/Kabupaten \& pemerintah desa, belanja donasi keuangan kepada propinsi/kabupaten \& pemerintah desa . Sedangkan Belanja Langsung mencakup belanja pegawai barang $\&$ jasa, Belanja Modal .

\section{Hipotesis Penelitian}

Berdasarkan teori di atas, maka terdapat hipotesis penelitian yaitu sebagai berikut :

H1 Di duga terdapat pengaruh yang signifikan antara Pendapatan Asli Daerah (PAD) terhadap Pemerintah Kota di Pulau Jawa .

H2 Di duga terdapat pengaruh yang signifikan antara Belanja Daerah terhadap Pemerintah Kota di Pulau Jawa .

H3 Diduga terdapat pengaruh yang signifikan antara Pendapatan Asli Daerah (PAD) terhadap Belanja Daerah pada Pemerintah Kota di Pulau Jawa .

\section{METODOLOGI PENELITIAN}

\section{Jenis Penelitian}

Penelitian ini menggunakan metode penelitian kuantitatif. Menurut Sugiyono (2017) metode penelitian kuantitatif dapat diartikan sebagai metode penelitian yang berlandaskan pada filsafat positivisme, digunakan untuk meneliti pada populasi atau sampel tertentu, pengumpulan data menggunakan instrumen penelitian, analisis data bersifat kuantitatif / statistik, dengan tujuan untuk menguji hipotesis yang telah ditetapkan .

Berdasarkan identifikasi masalah yang sudah dikemukakan sebelumnya, peneliti menggunakan jenis rumusan masalah asosiatif yang berbentuk hubungan sebab akibat (kausal) . Menurut Sugiyono (2017) rumusan masalah asosiatif adalah suatu rumusan masalah penelitian yang bersifat menanyakan hubungan antara dua variabel atau lebih .

\section{Operasional Variabel}


Tabel 1.

Operasionalisasi Variabel

\begin{tabular}{|c|l|l|}
\hline Variabel & \multicolumn{1}{|c|}{ Indikator } & $\begin{array}{c}\text { Skala } \\
\text { Ukur }\end{array}$ \\
\hline $\begin{array}{c}\text { Pendapatan } \\
\text { Asli }\end{array}$ & $\begin{array}{l}\text { 1. } \text { Pajak Daerah } \\
\text { 2. Retribusi Daerah }\end{array}$ & Rasio \\
& $\begin{array}{l}\text { Hasil Pengelolaan } \\
\text { Kekayaan Daerah yang } \\
\text { Dipisahkan } \\
\text { Lain-Lain PAD yang Sah }\end{array}$ & \\
\hline $\begin{array}{c}\text { 4. Y) } \\
\text { Belanja } \\
\text { Daerah }\end{array}$ & $\begin{array}{l}\text { 1. Belanja Tidak Langsung } \\
\text { Belanja Langsung }\end{array}$ & Rasio \\
\hline
\end{tabular}

\section{Teknik Pengumpulan Data}

Menurut Sugiyono (2017) teknik pengumpulan data merupakan langkah yang paling strategis dalam penelitian, karena tujuan utama dari penelitian adalah mendapatkan data. Tanpa mengetahui teknik pengumpulan data, maka peneliti tidak akan mendapatkan data yang memenuhi standar data yang ditetapkan. Pengumpulan data dapat dilakukan dalam berbagai setting, berbagai sumber, dan berbagai cara .

Berdasarkan sumbernya, penelitian ini menggunakan data sekunder. Menurut Sugiyono (2017) sumber sekunder merupakan sumber yang tidak langsung memberikan data kepada pengumpul data, misalnya lewat orang lain atau lewat dokumen . Data yang digunakan dalam penelitian ini adalah data yang diambil dari dokumen berupa laporan keuangan APBD yang diperoleh melalui website resmi www.djpkkemenkeu.co.id

\section{Teknik Sampling}

\section{Populasi}

Menurut Sugiyono (2017) populasi adalah wilayah generalisasi yang terdiri atas: obyek / subyek yang mempunyai kualitas dan karakteristik tertentu yang ditetapkan oleh peneliti untuk dipelajari dan kemudian ditarik kesimpulannya. Jadi populasi bukan hanya orang, tetapi juga obyek\& benda-benda alam yang lain . Populasi juga bukan sekedar jumlah yang masih ada padaobyek / subyek yang dipelajari, tetapi meliputi seluruh karakteristik / sifat yang dimiliki oleh subyek atau obyek itu .

Populasi yang digunakan dalam penelitian ini adalah Pemerintah Kota di Pulau Jawa yang berjumlah 34 Pemerintah Kota periode 2016-2019 .

\section{Sampel}

Menurut Sugiyono (2017) sampel adalah bagian dari jumlah dan karakteristik yang dimiliki oleh populasi tersebut. Jika populasi besar, \& peneliti nir mungkin menyelidiki seluruh yang terdapat dalam populasi, contohnya lantaran keterbatasan dana, energi \& waktu, maka peneliti bisa memakai sampel yg diambil menurut populasi itu . Apa yang dipelajari menurut sampel itu, kesimpulannya akan bisa diberlakukan untuk populasi . Untuk itu sampel yg diambil menurut populasi wajib benar -benar representatif (mewakili) .

Dalam penelitian ini menggunakan teknik sampling nonprobability sampling dengan teknik sampling purposive . Menurut Sugiyono (2017) "nonprobability sampling adalah teknik pengambilan sampel yang tidak memberi peluang / kesempatan sama bagi setiap unsur atau anggota populasi untuk dipilih menjadi sampel”. Sedangkan menurut Sugiyono (2017) teknik sampling purposive adalah teknik penentuan sampel dengan 
pertimbangan tertentu . Berdasarkan kriteria yang telah ditentukan, maka Kriteria untuk pemilihan sampel dalam penelitian ini yaitu sebagai berikut :

1. Pemerintah Kota yang terletak di Pulau Jawa.

2. Pemerintah Kota yang tidak mempunyai kelengkapan data selama periode 20162019.

3. Pemerintah Kota yang tidak menerbitkan laporan keuangan APBD.

4. Pemerintah Kota yang memiliki kelengkapan data laporan keuangan APBD yang dibutuhkan selama periode 2016-2019.

Berdasarkan kriteria pemilihan sampel di atas, maka sampel yang digunakan dalam penelitian ini adalah Pemerintah Kota yang memiliki kelengkapan data laporan keuangan APBD yang dibutuhkan oleh penulis selama periode 2016-2019 yaitu sebanyak 13 Pemerintah Kota .

\section{Teknik Analisis Data}

Teknik analisis yang digunakan dalam penelitian ini yaitu teknik analisis kuantitatif. Karena data nya berupa angka-angka, yakni untuk menguji pengaruh variabel pendapatan asli daerah terhadap belanja daerah. Untuk menganalisis perkara dan pengolahan data yang diperoleh supaya penelitian ini bisa mengambarkan hipotesis yg ada, maka penelitian ini akan dibantu menggunakan memakai pelaksanaan SPSS versi 25.0 supaya data yg didapatkan lebih akurat .

Teknik analisis data yang digunakan dalam penelitian ini yaitu analisis korelasi product moment, analisis koefisien determinasi, analisis regresi linier sederhana, dan uji $\mathrm{t}$.

\section{HASIL PENELITIAN DAN PEMBAHASAN}

\section{Analisis Korelasi Product Moment}

Analisis ini digunakan untuk mengetahui hubungan antara satu variabel independen terhadap satu variabel dependen . Berikut ini adalah hasil dari korelasi product moment dengan menggunakan aplikasi SPSS versi 25.0 yaitu :

Tabel 2.

Hasil Analisis Korelasi Product Moment

\begin{tabular}{|c|c|c|c|}
\hline \multicolumn{4}{|c|}{ Correlations } \\
\hline & & Pendapatan Asli & Pelania Rara \\
\hline \multirow[t]{3}{*}{ Pendapatan Asli Daerah } & Pearson Correlation & 1 & .931 \\
\hline & Sig. (2-tailed) & & .000 \\
\hline & $\mathrm{N}$ & 52 & 52 \\
\hline \multirow[t]{3}{*}{ Belanja Daerah } & Pearson Correlation & $.931^{*}$ & 1 \\
\hline & Sig. (2-tailed) & .000 & \\
\hline & $\mathrm{N}$ & 52 & 52 \\
\hline
\end{tabular}

Sumber: Output SPSS, data diolah

Dari hasil pengolahan data diatas, bahwa koefisien korelasi antara variabel Pendapatan Asli Daerah $\left(\mathrm{X}_{1}\right)$ terhadap Belanja Daerah $(\mathrm{Y})$ menghasilkan nilai $\mathrm{r}$ nya sebesar 0,931 .

Dapat disimpulkan bahwa didapatakan nilai sig. $(0,000<0,005)$ serta koefisien korelasi antara variabel Pendapatan Asli Daerah dan Belanja Daerah sebesar 0,931 yang berada pada interval 0.80-1.000 yaitu dikategorikan dalam korelasi sangat kuat .

\section{Analisis Regresi Linear Sederhana}

Penelitian ini digunakan regresi linear sederhana yang bertujuan untuk menguji pengaruh antara Pendapatan Asli Daerah (x) dengan Belanja Daerah (y) dimana hanya terdiri dari satu variabel independen dan satu variabel dependen. Dalam menentukan 
regresi linear sederhana dalam penelitian ini menggunakan bantuan program SPSS version 25.0, dengan hasil sebagai berikut :

Tabel 3.

Hasil Analisis Regresi Linear Sederhana

\begin{tabular}{|c|c|c|c|c|c|c|}
\hline \multicolumn{7}{|c|}{ Coefficients ${ }^{a}$} \\
\hline \multirow[b]{2}{*}{ Model } & & \multicolumn{2}{|c|}{ Unstandardized Coefficients } & \multirow{2}{*}{$\begin{array}{c}\text { Standardized } \\
\text { Coefficients } \\
\text { Beta }\end{array}$} & \multirow[b]{2}{*}{$\mathrm{T}$} & \multirow[b]{2}{*}{ Sig. } \\
\hline & & $\mathrm{B}$ & Std. Error & & & \\
\hline \multirow[t]{3}{*}{1} & (Constant) & 562546469755 & 49458981509. & & 11.374 & .000 \\
\hline & & .626 & 458 & & & \\
\hline & Pendapatan Asli Daerah & 2.049 & .113 & .931 & 18.056 & .000 \\
\hline
\end{tabular}

sumber: Output SPSS, data diolah

Berdasarkan pengolahan yang ada pada diatas, persamaan regresi liniear sederhananya merupakan sebagai berikut:

$$
\mathrm{Y}=562546469755.626+2.049 \mathrm{X}
$$

Dari persamaan di atas dapat didefinisikan sebagai berikut:

1. Maka dapat diambil kesimpulan berdasarkan persamaan regresi linear sederhana bahwa koefisien regresi variabel Pendapatan Asli Daerah (X) sebesar 2.049 dapat diartikan jika variabel independen lain nilainya tetap dan nilai variabel kinerja keuangan mengalami kenaikan 1, maka Belanja Daerah akan mengalami kenaikan sebesar 2.049 .

2. Karena koefisisen bernilai positif maka terjadi hubungan positif antara Pendapatan Asli Daerah (X) terhadap Belanja Daerah (Y) sehingga kenaikan dari Pendapatan Asli Daerah (X) mengakibatkan kenaikan pada Belanja Daerah (Y) .

\section{Analisis Koefisien Determinasi}

Koefisien determinasi digunakan untuk mengetahui besarnya presentase pengaruh variabel Pendapatan Asli Daerah (x) terhadap variabel Belanja Daerah (y). Berikut ini adalah hasil dari koefisien determinasi dengan menggunakan aplikasi SPSS versi 25.0 yaitu :

Tabel 4.

\section{Hasil Analisis Koefisien Determinasi}

\begin{tabular}{|c|c|c|c|c|}
\hline \multicolumn{5}{|c|}{ Model Summaryb } \\
\hline Model & $\mathrm{R}$ & R Square & $\begin{array}{l}\text { Adjusted R } \\
\text { Square }\end{array}$ & $\begin{array}{l}\text { Std. Error of the } \\
\text { Estimate }\end{array}$ \\
\hline 1 & $.931^{\mathrm{a}}$ & .867 & .864 & 222397584259.9 \\
\hline & & & & 4714 \\
\hline
\end{tabular}

a. Predictors: (Constant), Pendapatan Asli Daerah

Sumber: Output SPSS, data diolah

Dari hasil pengolahan data diatas, dapat diketahui bahwa nilai $\mathrm{R}^{2}$ yaitu sebesar 0,867 artinya presentase sumbangan pengaruh variabel Pendapatan Asli Daerah (X) terhadap variabel Belanja Daearah (Y) sebesar 86,7\%, sedangkan sisanya $13,3 \%$ dipengaruhi oleh variabel lain yang tidak dimasukkan pada penelitian ini .

\section{Pengujian Hipotesis}

\section{Uji t}

Dalam penelitian ini digunakan uji $\mathrm{t}$ untuk melihat ada atau tidaknya pengaruh yang signifikan dari Pendapatan Asli Daerah (x) terhadap Belanja Daerah (y) . Sugiyono 
(2017b) dalam menentukan kriteria menggunakan membandingkan $t$ hitung menggunakan $\mathrm{t}$ tabel, dalam taraf signifikansi dengan berpedoman menurut output pengujian yg dipakai jika $-\mathrm{t}$ tabel $<$-thitung atau $\mathrm{t}$ hitung $\leq \mathrm{t}$ tabel, maka Ho diterima $\&$ Ha ditolak". Sedangkan jika -t tabel $>-t$ hitung atau $t$ hitung $>t$ tabel, maka Ho ditolak \& Ha diterima. Berikut ini merupakan output penelitian menurut uji tmenggunakan menggunakan SPSS 25,0.

Tabel 5.

Hasil Uji t

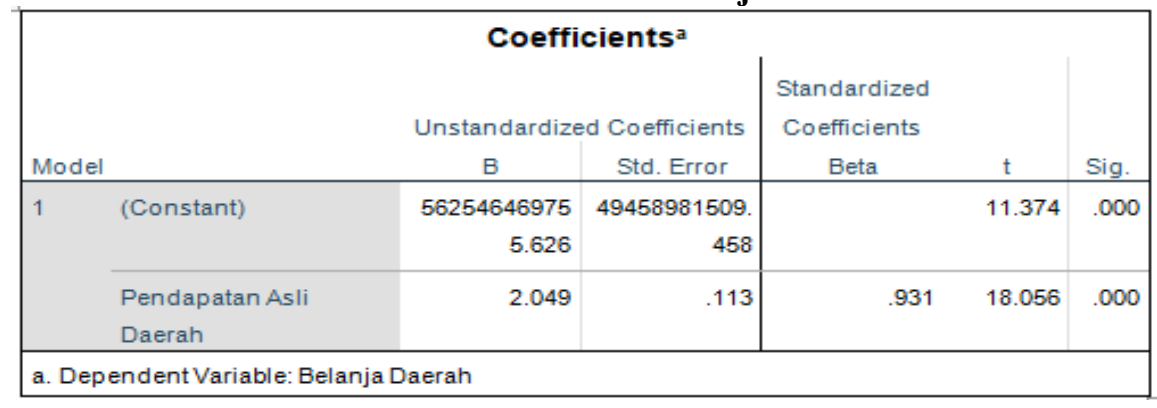

Sumber: Output SPSS, data diolah

Hasil uji $t$ dengan menggunakan SPSS Statistic 25.0 dalam tabel diatas antara variabel Pendapatan Asli Daerah terhadap Belanja Daerah yang dapat dilihat dari kolom $\mathrm{t}$ dalam coefficient menunjukkan bahwa nilai $t_{\text {hitung }}$ sebesar 18.056 . Dengan melihat pada $\mathrm{t}_{\text {tabel }}$ jumlah data $\mathrm{n}=52$ dan $(\mathrm{df})=\mathrm{n}-\mathrm{k}-1$ atau 52-1-1 $=50$ pada tingkat kesalahan $\alpha=0.05$ dengan pengujian dua pihak maka diperoleh $t_{\text {tabel }}$ sebesar 2.008 . Hal ini menunjukkan bahwa $t_{\text {hitung }}>t_{\text {tabel }}$ maka Ho ditolak dan Ha diterima. Artinya Pendapatan Asli Daerah secara parsial terdapat pengaruh yang signifikan terhadap Belanja Daerah .

Berikut adalah kurva dua pihak yang menggambarkan penerimaan $\mathrm{Ha}$ dan penolakan Ho :

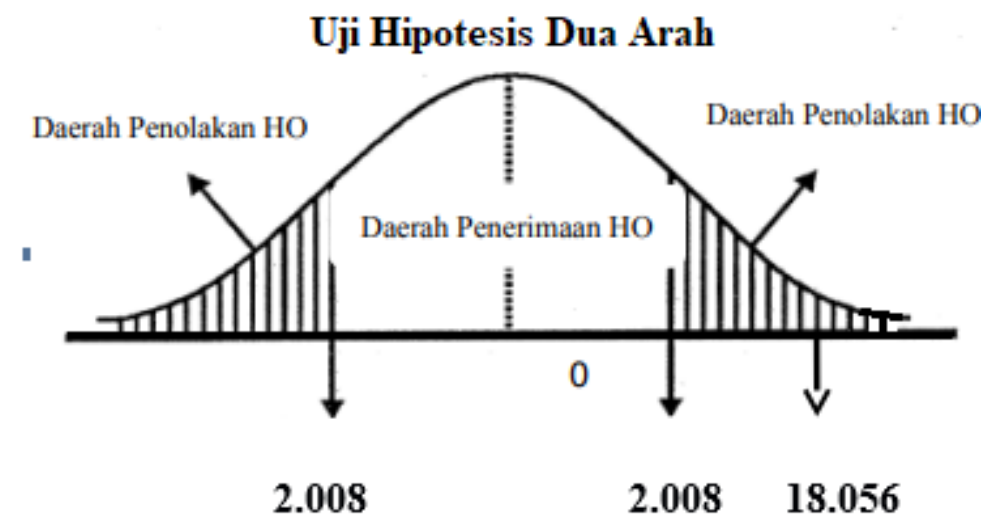

Gambar 2 Kurva Uji Dua Pihak (Two-tailed test)

Dapat dilihat pada gambar di atas, bahwa nilai t hitung sebesar 18.056 jatuh pada daerah penolakan Ho, sehingga dapat disimpulkan bahwa terdapat pengaruh yang signifikan antara Pendapatan Asli Daerahh terhadap Belanja Daerah pada Pemerintah Kota di Pulau Jawa .

\section{Pembahasan Hasil Penelitian}

\section{Pendapatan Asli Daerah pada Pemerintah Kota di Pulau Jawa}


Berdasarkan output pengujian yg dilakukan, maka diperoleh Pendapatan Asli Daerah tertinggi dimiliki oleh pemkot Depok dalam tahun 2017 yaitu sebesar 1,210,748,605,561. Sedangkan, Pendapatan Asli Daerah terendah dimiliki pemkot Batu dalam tahun 2016 yaitu 109,533,498,034. Melalui data Pendapatan Asli Daerah pemkot Depok dalam tahun 2017 ini adalah yg tertinggi menurut tahun lainnya yang berarti menampakan taraf ketergantungan wilayah terhadap donasi pemerintah sentra semakin rendah, sebagai akibatnya perlu menaikkan pasrtisipasi rakyat dalam membayar pajak \& retribusi wilayah .

Sebaliknya faktor penurunan terjadi karna rendahnya sumber penerimaan dari hasil pajak daerah, hasil retribusi daerah, hasil perushaan milik dan hasil pengelolaan kekayaan daerah lainnya yang dipisahkan, dan lain-lain pendapatan asli daerah yang sah. Oleh karena itu, diperoleh hasil terdapat pengaruh yang signifikan antara variabel Pendapatan Asli Daerah terhadap Pemerintah Kota di Pulau Jawa .

\section{Belanja Daerah pada Pemerintah Kota di Pulau Jawa}

Belanja Daerah adalah semua kewajiban daerah yang diakui sebagai pengurang nilai kekayaan bersih dalam periode tahun anggaran yang bersangkutan . Belanja daerah mencakup seluruh pengeluaran dari rekening kas generik wilayah yg mengurangi ekuitas dana, adalah kewajiban wilayah pada satu tahun aturan \& nir akan diperoleh pembayaran kembali sang wilayah. Belanja pemerintah daerah diklasifikasikan menurut 2 jenis belanja yaitu belanja pribadi \& nir pribadi .

Berdasarkan hasil pengujian yang dilakukan, maka diperoleh bahwa Belanja Daerah tertinggi dimiliki oleh Pemerintah Kota Depok pada tahun 2019 yaitu sebesar $3,769,161,518,807$. Sedangkan Belanja Daerah terendah dimiliki oleh Pemerintah Kota Batu terjadi pada tahun 2017 yaitu sebesar 779,141,659,105 . Adapun faktor peningkatan yang terjadi pada Belanja Daerah yaitu besar dana pendapatan maka semakin besar belanja daerah yang dilakukan pemerintah daerah untuk pembangunan di daerahnya masing-masing. Oleh karena itu, diperoleh hasil terdapat pengaruh yang signifikan antara variabel Belanja Daerah terhadap Pemerintah Kota di Pulau Jawa.

\section{Pengaruh Pendapatan Asli Daerah (PAD) terhadap Belanja Daerah pada Pemerintah Kota di Pulau Jawa}

Berdasarkan uji statistic yang dilakukan yaitu analisis koefisien product moment yang dinyatakan dengan koefisien korelasi (r), adapun besarnya koefisien korelasi antara pendapatan asli daerah dengan alokasi belanja modal berdasarkan perhitungan yaitu sebesar 0,931 yang berada pada interval $0,80-1,000$. Hal tadi memperlihatkan adanya dampak positif antara Pendapatan Asli Daerah terhadap Belanja Daerah yg termasuk pada kategori sangat kuat. Sehingga Pendapatan Asli Daerah dipengaruhi Belanja Daerah secara positif dimana hal tadi memperlihatkan bahwa Peningkatan Pendapatan Asli Daerah maka akan mengakibatkan peningkatan terhadap Belanja Daerah .

Adapun hasil uji t secara parsial, Pendapatan Asli Daerah mempunyai $t_{\text {hitung }}$ sebesar 18.056. dan $t_{\text {tabel }}$ sebesar 2.008 hal ini menunjukkan bahwa $t_{\text {hitung }}>t_{\text {tabel }}$ maka Ho ditolak dan Ha diterima, berarti secara parsial terdapat pengaruh signifikan antara variabel Pendapatan Asli Daerah terhadap Belanja Daerah. Berdasarkan hasil uji analisis korelasi regresi linear sederhana didapatkan persamaan linear $\mathrm{Y}=562546469755.626+2.049 \mathrm{X}$. Serta hasil dari koefisien determinasi yang diperoleh nilai $\mathrm{R}^{2}$ yaitu sebesar 0,867 artinya presentase sumbangan pengaruh variabel Pendapatan Asli Daerah (X) terhadap variabel Belanja Daearah (Y) sebesar 86,7\%, sedangkan sisanya $13,3 \%$ dipengaruhi oleh variabel lain yang tidak dimasukkan pada penelitian ini. Oleh 
karena itu, ketika pengujian hipotesis diperoleh hasil terdapat pengaruh yang signifikan antara variabel Pendapatan Asli Daerah terhadap Belanja Daerah .

Hasil penelitian ini sejalan dengan (Dermawan, Wildan, 2017) berjudul Pengaruh Pendapatam Asli Daerah (PAD) Terhadap Belanja Daerah . Hasil pengujian hipotesis menampakan bahwa pendapatan orisinil wilayah berpengaruhsignifikan terhadap belanja wilayah . Hal ini dipandang dari adanya impak Pendapatan Asli Daerah Terhadap Belanja Daerah secara signifikan ini berarti bahwa semakin semakin tinggi Pendapatan Asli Daerah maka akan semakin semakin tinggi juga Belanja Daerahnya .

\section{KESIMPULAN DAN SARAN}

\section{Kesimpulan}

Berdasarkan hasil analisis data dan pengujian ini dengan menggunakan bantuan program SPPS 25.0 pada bab sebelumnya, maka pengaruh Pendapatan Asli Daerah terhadap Belanja Daerah pada Pemerintah Kota di Pulau Jawa, dapat diambil kesimpulan sebagai berikut .

1. PAD di pemkot Pulau Jawa beflukktuasi disetiap tahunnya, ada yang menunjukkan kenaikan dan penuruannya. Melalui data Pendapatan Asli Daerah Pemerintah Kota Depok pada tahun 2017 ini merupakan yang tertinggi dari tahun lainnya yang berarti menunjukkan tingkat ketergantungan daerah terhadap bantuan pemerintah pusat semakin rendah, sehingga perlu meningkatkan pastisipasi masyarakat dalam membayar pajak dan retribusi daerah .

2. Belanja Daearah disetiap tahunnya juga mengalami berfluktuasi, ada yang menunjukkan kenaikan dan penuruannya. Adapun faktor peningkatan yang terjadi pada Belanja Daerah yaitu besar dana pendapatan maka semakin besar belanja daerah yang dilakukan pemerintah daerah untuk pembangunan di daerahnya masingmasing .

3. Hasil uji hipotesis secara parsial antaravariabel (X) Pendapatan Asli Daerah (PAD) terhadap variabel (Y) Belanja Daearah memberitahukan bahwa hipotesis Ha diterima dan Ho ditolak, yg artinya diduga masih ada imbas yang signifikan antara Pendapatan Asli Daerah (PAD) terhadap Belanja Daerah dalam pemkot pada Pulau Jawa.

Saran

Terdapat beberapa keterbatasan pada penelitian ini yg mungkin bisa mempengaruhi output penelitian yg dibuat, maka berdasarkan itu peneliti menaruh beberapa saran yang bisa bermanfaat buat peneliti selanjutnya, yaitu :

1. Bagi peneliti selanjutnya, disarankan untuk menambah variabel independen untuk mengetahui faktor-faktor lain yang dapat mempengaruhi Belanja Daerah (variabel dependen), seperti dana perimbangan dan lain-lain pendapatan daerah yang sah .

2. Penelitian selanjutnya diharapkan mengganti objek penelitian dan memperluasnya agar mendapatkan sampel yang lebih banyak, sehingga memungkinkan akan mendapatkan hasil penelitian yang mempengaruhi persistensi laba yang lebih akurat .

\section{DAFTAR PUSTAKA}

Amin, F. (2019). Penganggaran di Pemerintah Daerah. UB Press.

Dermawan, Wildan, D. (2017). Pengaruh Pendapatam Asli Daerah (PAD) Terhadap Belanja Daerah. Ilmiah EDUKASI, 5, 153.

Nurkholis, \& Khusaini, M. (2019). Penganggaran Sektor Publik. UB Press.

Permendragi Nomor 21. (2011).

Sugiyono. (2017a). Metode Penelitian Kuantitatif Kualitatif dan R\&D. CV ALFABETA. 
(Undang-Undang No.33 Pasal 1 Angka 18, 2004)

Wati, Masayu, R., \& Fajar, Catur, M. (2017). Pengaruh Pendapatan Asli Daerah dan Dana Perimbangan Terhadap Belanja Daerah Kota Bandung. Kajian Akuntansi, 1.

Wulandari, Phaureula, A., \& Iryanie, E. (2018). Pajak Daerah dalam Pendapatan Asli Daerah. CV BUDI UTAMA.

http://www.djpk.kemenkeu.go.id/portal/data/apbd 